\title{
Formation of critical metals-bearing massive sulfide ore bodies in Indonesia's largest zinc skarn deposit, Ruwai Mine, Central Borneo
}

\author{
CENDI DIAR PERMATA DANA ${ }^{1}$, ANDREA AGANGI ${ }^{1}$, \\ RYOHEI TAKAHASHI ${ }^{1}$ AND ARIFUDIN IDRUS ${ }^{2}$ \\ ${ }^{1}$ Akita University \\ ${ }^{2}$ Universitas Gadjah Mada \\ Presenting Author: cendi.diar@gmail.com
}

Ruwai is a $\mathrm{Zn}-\mathrm{Pb}$-Ag-skarn deposit located in the Schwaner Mountains, within the Central Borneo gold belt. The deposit is hosted by the Jurassic Ketapang Complex, and the interpreted causative intrusion is represented by the Mesozoic Sukadana granitoids. Most $\mathrm{Zn}, \mathrm{Pb}$ and $\mathrm{Ag}$ production has historically come from massive sulfide bodies. However, the available information on the mineralogy and geochemical characteristics of this deposits is very limited. This study provides a detailed description of the mineralogy, chemical compositions, and sulfur isotope compositions of the deposit, which give insight on the formation of massive sulfide ore bodies in skarn deposits.

This research revealed that the Ruwai ore bodies also contain non-negligible critical metals occurring as REE-, Bi-, Sb-, and Co-bearing minerals. REE-bearing minerals are hosted in both prograde and retrograde stages of skarn deposition. Whole-rock chemical analyses indicate that both causative intrusions and limestone host rock were enriched in $\mathrm{Pb}$ but depleted in $\mathrm{Au}$ during skarn deposition, which is consistent with the fact that the mineralization formed is base metals, instead of precious metals, as found in other areas of the same metallogenic belt. In this study we found that most metals in skarn and associated ore bodies show co-occurring enrichment or depletion relative to the limestone and intrusive rocks. However, this pattern is not observed for $\mathrm{Pb}$ and $\mathrm{Zn}$, which are enriched only in massive sulfide samples, but are depleted in the remaining samples. Thus, $\mathrm{Pb}$ and $\mathrm{Zn}$ in the hydrothermal system were consumed predominantly for the massive sulfide.

Sulfur isotopic analyses indicate that massive sulfide ore samples located relatively far from the causative intrusion have higher S-isotope values $\left(\delta^{34} \mathrm{~S}=2.9-4.9 \%\right.$ ) compared to those of disseminated ore samples located close to the intrusion $\left(\delta^{34} \mathrm{~S}=\right.$ $0.4-3.4 \%$ ). This isotopic variation might be caused by mixing of sulfur source and/or reduction of $\mathrm{SO}_{4}{ }^{2-}$ produced from disproportionation of $\mathrm{SO}_{2}$ at temperature below $\sim 400^{\circ} \mathrm{C}$ by methane and/or iron. This reduction also may have been the source of most of the isotopically heavier sulfur within the massive sulfide bodies. 